\title{
BRIDGING THE CONCEPTUAL GAP BETWEEN LAW AND Morality: A CRITICAL RESPONSE TO H.L.A. HART'S THE CONCEPT OF LAW
}

\author{
Kaila Morin
}

\begin{abstract}
In The Concept of Law, H.L.A. Hart develops his theory for a concept of law that rejects the possibility of a necessary connection between law and moralityi.e., what the law is from what the law ought to be. He admittedly does so for moral reasons. If there is a conceptual gap between law and morality, it is possible to use the latter as a critical standard for assessing the law by questioning 'is this law too iniquitous to obey or apply?' However, this concept of law is flawed. If the human capacity for moral reason can be used to correctly identify and disobey legally valid though morally deplorable laws, one must assume that belief in what the law ought to be is an inherently moral aspect of the internal point of view. Furthermore, unless one chooses to acknowledge the suppositions of command theory - that is, that law is nothing more than habitual congruencies or the command of a supreme sovereignone must assume Hart's idea of the ultimate rule of recognition as an external statement of fact relating to societies internal perspective of what ought to be. In this way, the inclusion of the internal perspective as a necessary aspect of law entails a connection between law and morality. Otherwise, what law is and what law ought to be become synonymous under a merely external viewpoint. This does not reflect the reality of how individuals assess the law or their actions in relation to the law.
\end{abstract}

\section{A. INTRODUCTION}

First published in 1961, legal philosopher H.L.A. Hart constructs a comprehensive argument for his positivist concept of law in The Concept of Law. Hart affirms that his aim is not to conceptualize and prescribe a definition of law, but to "further the understanding of law, coercion, and morality as different but related social phenomena." ${ }^{1}$ Accordingly, Hart underlines three important areas of inquiry: 'How does law differ from and how is it related to orders backed by threats? How does legal obligation differ from, and how is it related to, moral obligations? What are rules and to what extent is law an affair of rules? ${ }^{2}$ Via this descriptive approach, Hart advances his concept of law by refuting the idea of

\footnotetext{
${ }^{1}$ HLA Hart, The Concept of Law (2nd edn, OUP 1997) vi.

2 ibid 13.
} 
coercion in Austin's command theory while also providing for the possibility of a positivist separation between what law is and what law ought to be. This second aspect of Hart's theory-the separation thesishas generated notable controversies (particularly, the Fuller-Hart and Dworkin-Hart debates), and arguably remains his most problematic conceptual premise. ${ }^{3}$

In this paper, I will add to the Fuller/Dworkin side of the debate on morality and law by providing a further response to Hart's concept of law. Although Hart provides a thorough justification for the reality and desirability of this distinction, his argument is susceptible to additional counter-arguments relating to two logical inconsistencies in his reasoning. First, the concepts of law and morality are necessarily bound provided that Hart yields to his theory of law as a system of rules rather than a system of orders backed by threats. By recognizing the human capacity for moral reason, Hart provides for the moral character of the internal viewpoint. The internal aspect of rules - which distinguishes a rule from a habit - indicates that the ultimate rule of recognition emerges from this internal viewpoint as a first step from the pre-legal into the legal world. ${ }^{4}$ Given that the validity of law is an internal statement itself recognizing the rule of recognition, Hart links the validity of law to morality. ${ }^{5}$ Second, requirements under the primary rules of obligation conflict with Hart's concept of a law too iniquitous to obey. These contradictory assertions necessarily provide for the moral nature of law as

\footnotetext{
${ }^{3}$ For a better understanding of Hart's separation thesis, see Hart, Concept of Law (n 1) vi: 'law, coercion, and morality as different but related social phenomena.' See also HLA Hart, 'Positivism and the Separation of Law and Morals' (1958) 71:4 Harvard Law Review 593. Hart distinguishes his separation thesis from those of Bentham and Austin, 'which deserved criticism' as they insisted on a complete separation between law and morality, and rather maintains that - while law need not coincide with morality in order to be valid ('[l]aws, however morally iniquitous, would still (so far as this point is concerned) be laws') - law and morality are interrelated in that the later may be used to criticize the former. This is key to Hart's concept of law, and to legal positivism in general. Although a number of prominent positivist theorists maintain that law and morality are related, legal positivism entails that law need not satisfy ideals of morality. Legal positivism views law as a procedurally generated social construction, therefore its existence as law is entirely separate from the merit of its content. In this sense, legal positivism must accept the idea that valid law need not adhere to moral values.

${ }_{5}^{4}$ Hart, Concept of Law (n 1) 56, 94.

${ }^{5}$ ibid $104-105$.
} 
a system of rules.

To begin, I will describe and assess Hart's concept of law in the following section. I will then provide a more detailed analysis of the logical inconsistencies in Hart's theory in order to bridge the conceptual gap between law and morality. It is crucial to note that this response does not assume that morality includes 'all sorts of extra-legal notions about 'what ought to be,' regardless of their sources, pretensions, or intrinsic worth. ${ }^{6}$ Moral values are best understood as those governing interpersonal relations in a way that prevents the instrumentalization of others, and upholds for them a standard of treatment that one would wish for oneself. Furthermore, I acknowledge that moral and legal rules are distinct, and that both the obligations they impose and the sanctions they warrant differ. ${ }^{7}$ However, this distinction does not itself provide for the separation of law and morality; a necessary connection does not imply that all moral rules are law, but merely requires that all legal rules conform to moral values - i.e., that valid law cannot be immoral. ${ }^{8}$

\footnotetext{
${ }^{6}$ Lon L Fuller, 'Positivism and Fidelity to Law: A Reply to Professor Hart' (1958) 71:4 Harvard Law Review 630, 635.

${ }^{7}$ Hart, Concept of Law (n 1) 86. Hart's assessment of law and morality generally focuses on the distinction between moral and legal obligations in order to defend the separation thesis.

${ }^{8}$ Like John Finnis in Natural Law and Natural Rights (OUP 1980) 9-18, I argue that the internal point of view must consider moral concerns in its assessment of the law, thereby ensuring a connection between law and morality. While Finnis does so using Aristotle's work on the central case and focal meaning, both positions maintain the connection between law and morality, even in laws with no particular moral content, or which have been adopted for self-interested reasons, by stating that these are secondary to the moral central case, or must correspond with the moral assessment of the internal viewpoint and cannot be deemed 'too iniquitous to obey'. However, there are some key distinctions between Finnis' argument and those forwarded in this essay. For one, Finnis conflates Hart's internal viewpoint with Raz's legal viewpoint, which I maintain are distinct. The legal viewpoint - through which people make detached normative statements on what the law is, and how they should act in relation to itpresupposes the existence of valid legal norms or a legal system, and does not effectively provide for their internal assessment by those who use and follow them (see footnote 28). Although both viewpoints can work concomitantly, the internal point of view takes precedence over the legal, as it more correctly reflects the reality of how those who use the law also assess it in order to determine their and others' behaviour by questioning whether a law is 'too iniquitous to obey'. An understanding of the internal viewpoint as distinct from the legal more effectively provides for the moral aspect of the internal viewpoint, as it is possible to conceive of an amoral legal viewpoint through which one adopts a detached normative statement of legal facts to
} 


\section{B. HART'S CONCEPT OF LAW}

In a thorough attempt to descriptively analyze law and its separation from morality, Hart provides the conceptual framework for his theory of law as a system of rules rather than a system of orders backed by threats. Having identified and critically assessed the basic elements of Austin's imperative theory, Hart finds that 'the simple model of law as the sovereign's coercive orders failed to reproduce some of the salient features of a legal system. ${ }^{9}$ The simple elements of commands and habits do not effectively account for some laws - namely power conferring laws and legal customs-, and fail to reproduce the features of continuity and universal applicability found in modern legal systems. Therefore, Hart affirms that law is not the gunman situation writ large; these features can only be found in the idea of a rule.

Contrasting the simple elements of commands and habits, Hart maintains that the idea of a rule is by no means a simple one. In order to accurately illustrate the complexity of a legal system, Hart claims that it is first necessary to discriminate between two different though related types of rules. 'Rules of the first type impose duties [primary rules of obligation]; rules of the second type confer powers, public or private [secondary rules of recognition, change, and adjudication]. ${ }^{, 10}$ The union of these rules is central to Hart's concept, although it is not a necessary precondition for the existence of law. Accordingly, Hart affirms:

[I]n the combination of these two types of rule there lies what Austin wrongly claimed to have found in the notion of coercive orders, namely 'the key to the science of jurisprudence'. [However] [w]e shall not indeed claim that wherever the word 'law' is 'properly' used this combination of primary and secondary rules is to be found; for it is clear that the diverse range of cases of which the word 'law' is used are not linked by any such simple uniformity

determine his or her behaviour, regardless of the 'practical reasonableness' of morality. I also relate the moral aspect of the internal viewpoint and notions of a law 'too iniquitous to obey' to the notion of obligation as a necessary aspect of a legal rule in order to further demonstrate that immoral laws (those which one is not obligated to follow) cannot be said to exist as valid legal rules. This more effectively proves a connection between valid legal rules and moral values. Finnis' account allows for the validity of immoral laws, regardless of how practically unreasonable they might be.

${ }^{9}$ Hart, Concept of Law (n 1) 79.

${ }^{10}$ ibid 81 . 
$[\ldots] .{ }^{11}$

Under this model, the word 'law' can be 'properly' used in the absence of secondary rules, however, for law to exist, human conduct must in some sense be 'non-optional or obligatory' (i.e., the legal subject must in some sense feel bound by primary rules of obligation that restrict certain types of conduct). ${ }^{12}$ For this reason, Hart acknowledges that it is possible to imagine a primitive society in which social control is limited to the internalization of its primary rules of obligation. ${ }^{13}$ This social structure 'of primary rules of obligation' can only exist in a small community 'closely knit by ties of kinship, common sentiment, and belief, and placed in a stable environment. ${ }^{14}$ Under any other condition, emerging problems of uncertainty and inefficiency are exacerbated by the static character of the primary rules and are only remedied by the secondary rules of recognition, adjudication and change.

Hart further contrasts between the idea of a rule and the elements of commands and habits by separating the legal validity of rules from the physical power of their authors. According to Hart, the validity of a rule is determined by reference to accepted rules of recognition. Rules of recognition cannot themselves be valid, only accepted, because they 'cannot meet tests stipulated by a more fundamental rule. ${ }^{15}$ Courts and others who accept as appropriate certain rules of recognition use these in order to make an internal statement on the legal validity of particular rules. In this sense, the rule of recognition - which can neither be asserted by a sovereign nor accepted as habitual obedience, but is rather shown to exist in the way laws are identified - serves as a kind of gateway into a system of modern law. The rule of recognition-shown to exist as a matter of fact through its usage and acceptance in identifying valid laws through the internal viewpoint-is ultimate in the identification of valid law, not the sovereign. This contradicts the elements of command theory

\footnotetext{
11 ibid.

${ }^{12}$ See Hart, Concept of Law, ibid 82, 91. Note that Hart distinguishes between the assertion that someone had an obligation to do something and the assertion that someone was obliged to do it in his portrayal of law as obligatory.

13 ibid 91, see also at 56. The conscious acceptance of social rules as correct standards for behaviour is called 'the internal aspect of rules.' This distinguishes a rule from a habit.

${ }^{14}$ ibid 92.

15 ibid 100-107.
} 
and habitual obedience.

Of course, in his theory of law as a system of rules, Hart attempts to "further the understanding of law, coercion, and morality as different but related phenomena. ${ }^{16}$ As a result, his concept of law also seeks to reject the possibility of a necessary connection between law and morality-i.e., what the law is from what the law ought to be. Hart admittedly does so for moral reasons. If there is a conceptual gap between law and morality, it is possible to use the latter as a critical standard for assessing the law by questioning, 'This is law but [is it] too iniquitous to obey or apply?"17 In this sense, the legal subject can more effectively assess what the law is according to an internal statement of what the law ought to be, and use this assessment in deciding whether or not to obey.

Hart forwards several arguments in support of this distinction, many of which I will now dismiss. For one, Hart's attempt to disentangle justice - specifically the precept of treating 'like cases alike' - from the general spheres of law and morality is not relevant to this assessment. In order to provide an accurate understanding of law in relation to morality, the concept of morality must be considered in its entirety. Therefore, it would be counter-productive to limit this response to a particular kind of morality. Furthermore, Hart maintains that legal rules are different than, and therefore separate from, moral rules as they impose distinct obligations and warrant more severe sanctions. ${ }^{18}$ While true, this argument is also irrelevant. It falsely assumes the conflation of moral and legal rules. The connection of law and morality does not imply that all moral rules are law; it merely requires that valid laws are not immoral.

Hart's argument relating to the nature of purely procedural laws is also extraneous to this assessment. Although more relevant, it cannot invalidate the connection between legal validity and morality, and is therefore dismissed. In his postscript, Hart responds to Dworkin in an attempt to uphold his claim that 'there are no necessary conceptual connections between the content of law and morality. ${ }^{19}$ He argues that, in addition to morally iniquitous laws, 'there can be legal rights and duties

\footnotetext{
${ }^{16}$ ibid vi (emphasis added).

17 ibid 210.

18 ibid $86,169-170$.

19 ibid 268.
} 
which have no moral justification or force whatever. ${ }^{20}$ However, this argument also falsely assumes the conflation of moral and legal rules. A necessary connection does not imply that all laws are moral rules; it merely requires that valid laws are not immoral. The procedural rule is only valid if it is not immoral. Its content does not itself need to be moral.

Moreover, Hart does not sufficiently maintain this argument. In a separate article, Terry Nardin adopts the Kantian perspective of morality while describing its relation to law; 'The word 'moral' in this context signals a non-instrumental relationship in which human beings treat one another not as obstacles to be overcome or resources to be used, but as persons whose autonomy should be respected. ${ }^{, 21}$ Understood in this way, even purely procedural rules are in some sense moral as they regulate our interactions in order to ensure the non-instrumentalization of other individuals. Therefore, it is not possible to assume the amoral quality of such rules.

Hart's most important argument for the distinction between law and morality relates to his notion of a 'wicked law'. In an attempt to justify both the reality and the desirability of a separation, Hart makes the following empirical assumption:

[I]t scarcely seems that an effort to train and educate men in the use of a narrower concept of legal validity, in which there is no place for valid but morally iniquitous laws, is likely to lead to a stiffening of resistance to evil, in the face of threats of organized power, or a clearer realization of what is morally at stake when obedience is demanded. So long as human beings can gain sufficient co-operation from some to enable them to dominate others, they will use the forms of law as one of their instruments. Wicked men will enact wicked rules which others will enforce. ${ }^{22}$

Accordingly, Hart implies that morally iniquitous law is not only real, but also inevitable. He also assumes that wicked law is most effectively remedied by the separation of law and morality. Referring specifically to the laws of slave-owning societies, as well as the nearer parallels of Nazi Germany and South Africa, Hart argues that this separation is necessary

\footnotetext{
${ }^{20}$ ibid.

${ }^{21}$ Terry Nardin, 'Emergency logic: prudence, morality and the rule of law' in Victor Ramraj (ed), Emergencies and the Limits of Legality (Cambridge University Press 2008) 97.

${ }^{22}$ Hart, Concept of Law (n 1) 210.
} 
in order to prevent the perversion of morality under a system of wicked laws, and to empower legal subjects with the ability to defy 'laws that are too iniquitous to obey. ${ }^{23}$

\section{Law Without Morality: The Fallacies of a LaW too INIQUITOUS TO OBEY}

In his concept of law, Hart purposefully analyzes the resemblances and differences between law and morality in order to provide for the separation of these long-entangled ideas. As a result, the theoretical framework for his concept of law as a system of rules aims to refute the possibility of a necessary connection between law and morality. This way, the legal subject can assess what the law is in relation to what the law ought to be by questioning, 'is this law too iniquitous to obey or apply?' If yes, the wicked law can be broken, however it remains law. The separation between law and morality designates that iniquitous law remains valid law, and that noncompliance "merely means that human beings do not do what they are told to do. ${ }^{24}$ As I will now argue, this concept of law is logically unsound, making it susceptible to two counterarguments based on the reasoning in Hart's theoretical framework. Although Hart aims to separate law from morality, the contradictory aspects of his concept necessarily provide for the moral nature of law as a system of rules.

\section{The Concepts of Law and Morality are Necessarily Bound provided that Hart Yields to His Theory of Law as a System of Rules rather than a System of Orders backed by Threats}

According to Hart, rules are different from the simple elements of commands and habits because of their internal aspect. A rule (in lieu of a command or a habit) exists either if it has been validated by a previously accepted rule of recognition, or if its acceptance is shown through its use as a common standard of behaviour. ${ }^{25}$ Under both instances, the rule must be internally acknowledged (contrasting the idea of a habit), and either directly or indirectly-through validation under a previously accepted

\footnotetext{
23 ibid 200.

24 ibid 187.

${ }^{25}$ ibid 56-57.
} 
rule-accepted (contrasting the idea of a command). This is only achieved when the subjects of a particular rule adopt an internal viewpoint - that is, 'the view of those who do not merely record and predict behaviour conforming to rules [external viewpoint], but use the rules as standards for the appraisal of their own and others' behaviour'-in order to critically reflect on it. ${ }^{26}$ More specifically, Hart

${ }^{26}$ ibid 56-57, 98. Although similar, Hart's internal viewpoint differs slightly from Raz's legal point of view. See Joseph Raz, The Authority of Law (OUP 1979) 153157, as well as Joseph Raz, Practical Reason and Norms (OUP 2002) 170-177. The legal viewpoint - through which people make detached normative statements on what the law is, and how they should act in relation to it-presupposes the existence of valid legal norms or a legal system, and does not effectively provide for their internal assessment by those who use and follow them. It is inherently legal in that the law is meant to underscore the standards for ones behaviour; it provides for an assessment of what 'ought' to be a person's behaviour based solely on the law. Hart's internal viewpoint provides for an extra-legal standard of assessment in determining one's own or others' behaviour through the question 'is this law too iniquitous to obey?'i.e., people must first question whether a law is too iniquitous to obey in order to assess what 'ought' to be a one's behaviour.

While both Raz and Hart maintain that a valid legal system does not require 'that its norm subjects are ideal law-abiding citizens or that they should be so' (Raz, Practical Reason 171), but merely that 'at least the officials of the system [...] accept its laws and follow them' (Raz, Authority of Law 155) (this does provide for some level of dissent with regard to the law), the internal viewpoint allows for even officials of the legal system to stray from laws deemed too iniquitous to obey, thereby invalidating it, whereas the legal viewpoint does not. Under the internal viewpoint, any individual who deems a law too iniquitous to obey-even the officials of a system - can choose not to uphold it as an appropriate standard of behaviour because of this internal assessment, whereas a judge who adopts the legal point of view must acknowledge what the law is, and assess behaviour in relation to this.

Indeed, only when viewed as distinct and together can these viewpoints provide for the case of the anarchist judge described by Raz (Raz, Practical Reason 148). Under this conception, what the anarchist judge chooses to uphold would differ depending on whether he adheres to the legal viewpoint or the internal viewpoint; he could determine that the law is too iniquitous to obey under the internal viewpoint, or could maintain that the law is a valid law and insist on its being upheld under the legal viewpoint. This marks a very slight but key distinction between the two viewpoints. Although both can work concomitantly, Hart's internal point of view is considered here as it more correctly reflects the reality of how those who use the law also assess it in order to determine their and others' behaviour, and therefore takes precedence over the legal. See for example cases where the law is deemed immoral and is therefore resisted by the oppressed, or the case of Nazi Germany, where the law was immoral yet followed and accepted by many. These laws, which were initially upheld, were shown to have been invalid after the fact through ex post facto criminal sentencing due to their immorality. While it is true that the internal viewpoint may be 
affirms:

What is necessary is that there be a critical reflective attitude to certain patterns of behaviour as a common standard, and that this should display itself in criticism (including self-criticism), demands for conformity, and in acknowledgements that such criticism and demands are justified, all of which find their characteristic expression in the normative terminology of 'ought', 'must', and 'should', 'right' and 'wrong..

In this sense, laws are made 'non-optional or obligatory' through an internal statement of duty or obligation resulting from its direct or indirect acceptance as a common standard of behaviour. Accordingly, obedience generally results from an internal recognition of the law as an accepted social standard - i.e., members of a society will generally choose to obey the law if it is accepted and viewed internally as a standard for how one 'ought', 'must', or 'should' behave, or what it is 'right' and 'wrong' to do. Hart maintains that some members may still choose to disobey a law that is accepted if the social pressure is weak, however it remains a standard for how they 'ought' or 'should' behave; ' $[\mathrm{t}]$ here is no contradiction in saying that people accept certain rules but experience no such feelings of compulsion. ${ }^{28}$

Hart explicitly qualifies the question of obedience-expressed critically through the normative terminology of 'ought', 'must', and 'should', rather than merely expressed out of disrespect for accepted rules of conduct —as a moral..$^{29}$ Questions such as 'Am I to do this evil thing?' or 'This is law but too iniquitous to obey or apply?' require that the legal subject pass a moral judgment regarding the law's desirability as a standard of conduct. This necessarily presupposes a capacity for moral reasoning, which must be used to critically reflect on whether a particular law 'should' be obeyed. In this sense, the internal viewpoint-i.e., the critical reflective attitude towards certain standards of behaviour-is essentially a moral consideration.

Having differentiated between the idea of a rule and the simple

based on different motives and considerations (Hart, Concept of Law (n 1) 198), and that a number of laws may not be morally justified, the law itself cannot be too iniquitous to obey, and therefore valid law cannot be immoral. It is in this sense that there exists a necessary connection between law and morality.

${ }^{27}$ Hart, Concept of Law (n 1) 21057.

28 ibid.

${ }^{29}$ ibid 211. 
elements of commands and habits, Hart maintains that only the former can account for many of the important features of a legal system. More specifically, the notion of an accepted rule of recognition is required for an understanding of the foundations of a legal system and the idea of legal validity. ${ }^{30}$ This reflects the empirical and conceptual ultimacy of the rule in Hart's concept of law. As the first step from the pre-legal into the legal world, it both necessarily precludes and is presupposed by the other secondary rules, and provides for the identification of primary rules. ${ }^{31}$

As indicated in the previous section, Hart introduces the rule of recognition in order to remedy the defect of uncertainty in primitive social structures. Doubts as to what the rules are or as to the precise scope of some given rule are dispelled when an accepted rule of recognition specifies what constitutes valid law. ${ }^{32}$ For this reason, the rule of recognition itself 'can neither be valid nor invalid but is simply accepted. ${ }^{33}$ It is not stated, but instead 'its existence is shown in the way in which particular rules are identified, either by courts or other officials or private persons or their advisers. ${ }^{34}$ According to Hart, 'the ultimate rule of recognition may be regarded from two points of view: one is expressed in the external statement of fact that the rule exists in the actual practice of the system; the other is expressed in the internal statements of validity made by those who use it in identifying the law. ${ }^{, 35}$

Assessed in relation to the moral character of the internal perspective, this conception of the rule of recognition is necessarily moral. As mentioned, questions such as 'Am I to do this evil thing?' or 'This is law but too iniquitous to obey or apply?' presuppose the moral character of the internal viewpoint by requiring a moral judgment of the law's desirability as a standard of conduct. This permits the legal subject to decide whether the law 'should' be used (i.e. obeyed). As a result, the acceptance of a rule, which is necessarily shown through its use as a standard of behaviour, depends on a moral assessment of whether or not it 'should' be used as a standard of conduct. In order for it to exist as 'an

\footnotetext{
${ }^{30}$ ibid 202.

31 ibid 91-96.

32 ibid 100-107.

33 ibid 109.

34 ibid 101 .

35 ibid 112.
} 
external statement of the fact that a certain mode of behaviour was generally accepted' or for its existence to be 'shown in the way in which particular rules are identified,' the rule of recognition cannot logically have been deemed 'too iniquitous to obey or apply. ${ }^{36}$ Unless Hart rejects the internal aspect and assumes that laws are either habitual congruencies or orders backed by threats, the rule of recognition must have conformed to society's general conception of morality in order to become generally accepted.

This finding is also supported by Hart's assessment of morality in pre-legal societies. Again, he assumes the inherent capacity for moral reason by maintaining that accepted rules of obligation likely reflected society's morals; 'at that stage [in which primary rules of obligation were the only means of social control] there might be nothing corresponding to the clear distinction made, in more developed societies, between legal and moral rules. ${ }^{37}$ In the absence of a rule stating what the law is, members of a social group must act according to what they believe the law out to be. Given that its own existence as the first step from the pre-legal into the legal world is nothing more than 'an external statement of the fact that a certain mode of behaviour was generally accepted as a standard of practice,' the rule of recognition will necessarily reflect what the law ought to be in determining what may be considered valid law. ${ }^{38}$ Given that the validity of law is an internal statement itself recognizing and utilizing the criteria set out in the rule of recognition, Hart links the validity of all law to morality.

In brief, unless one chooses to acknowledge the suppositions of command theory - that is, that law is nothing more than habitual congruencies or the command of a supreme sovereign - or to refute the human capacity for moral reason, one must assume that the ultimate rule of recognition is an external statement of fact relating to societies internal perspective of what the law ought to be. Accordingly, the inclusion of the internal perspective as a necessary aspect of law entails a connection between law and morality. Otherwise, what law is and what law ought to be become synonymous under a merely external viewpoint. This does not

\footnotetext{
36 ibid 101, 110, 210.

${ }^{37}$ ibid 169.

38 ibid 110.
} 
reflect the reality of how individuals assess the law or their actions in relation to the law.

\section{Requirements under the Primary Rules of Obligation Conflict with Hart's Conception of a Law too Iniquitous to Obey}

According to Hart, the word 'law' can be 'properly' used in the absence of secondary rules, however they cannot exist in the absence of primary rules of obligation (ex., customs, primitive law and international law). Law exists where "human conduct is made in some sense non-optional or obligatory' (i.e., the legal subject must in some sense feel bound by primary rules of obligation that restrict certain types of conduct). ${ }^{39}$ Indeed, Hart quite explicitly states that his own concept of law remains premised on the idea of a necessary obligation:

It will be recalled that the theory of law as coercive orders, notwithstanding its errors, started from the perfectly correct appreciation of the fact that where there is law, there human conduct is made in some sense non-optional or obligatory. In choosing this starting point the theory was well inspired, and in building up a new account of law in terms of the interplay of primary and secondary rules we too shall start from the same idea. ${ }^{40}$

Hart characterizes the idea obligation in three ways: (1) '[T]he insistence on importance or seriousness of social pressure behind the rules is the primary factor determining whether they are thought of as giving rise to obligations." (2) 'The rules supported by this serious pressure are thought important because they are believed to be necessary to the maintenance of social life or some highly prized feature of it. ${ }^{42}$ (3) ' $[\mathrm{T}] \mathrm{he}$ conduct required by these rules may, while benefiting others, conflict with what the person who owes the duty may wish to do. ${ }^{43}$ In addition, Hart states that a society of primary rules of obligation 'must contain in some form restrictions on the free use of violence, theft, and deception,' which must be generally accepted by the majority in order to ensure sufficient social pressure. ${ }^{44}$ Finally, the internal aspect of rules requires

\footnotetext{
${ }^{39}$ ibid 82.

${ }^{40}$ ibid.

41 ibid 87.

42 ibid (emphasis added).

43 ibid.

${ }^{44}$ ibid 91-92.
} 
that these feelings be displayed in criticism (including self-criticism) of members through a 'use [of] the rules as standards for the appraisal of their own and others' behaviour. ${ }^{45}$

This provides for a second much simpler, although no less important, criticism of Hart's concept of law. In his attempt to distinguish between law and morality, Hart provides the legal subject with a critical standard for the assessment of valid law. He states that 'the certification of something as legally valid is not conclusive of the question of obedience, and that, however great the aura of majesty or authority which the official system may have, its demands in the end must be submitted to moral scrutiny. ${ }^{46}$ This is also maintained in Hart's explicit assertion that the question of obedience - expressed in 'ought', 'must', and 'should', rather than the mere refusal to comply with accepted rules of conduct-is a moral one. ${ }^{47}$

As a result, every law is subject to moral scrutiny and may be justifiably disobeyed, by questioning, 'Am I to do this evil thing?' or 'This is law but too iniquitous to obey or apply?' In fact, in a separate though related article, Hart maintains that a morally iniquitous law may not only be justifiably disobeyed, but that disobedience may have been legally required under the precepts of ex post facto law. Adhering to his claim that wicked law is still valid law, Hart rejects the idea an individual can be prosecuted for an act that was committed under a law that is invalidated by wicked character. Instead, the courts-who, from the internal viewpoint, use commonly accepted standards of correct in identifying the rules of a system - might punish the individual 'under a new retrospective law and declare overtly that we [those who did not disobey the wicked law] were doing something inconsistent with our principles. $^{\text {. }} 8$

This is problematic for a number of reasons. For one, an ex post facto law in which the wicked acts are made punishable because they were 'inconsistent with our principles' is necessarily an invalidation of wicked laws for moral reasons. The assumption that a court, in adopting the internal viewpoint, would recognize that immoral acts are inconsistent

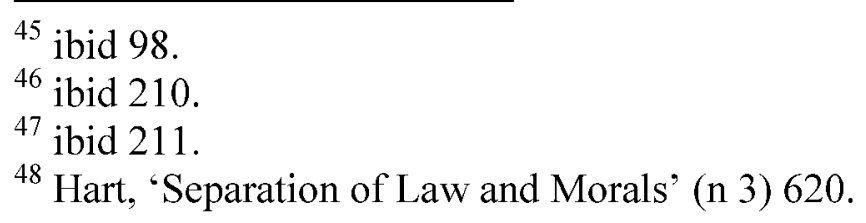


with society's principles, and should therefore be legally reprimanded despite its formal legality, inherently presupposes a moral judgement on the acceptance of a wicked law as a standard. In addition, the inconsistent use of moral principles as standards for accepted conduct fails to remedy the defect of uncertainty. The idea that a wicked law could remain law despite its immorality, but that 'legal' acts could then be prosecuted under a new law that repeals the former for being inconsistent with our [presumably moral] principles' is inherently flawed as it assumes a moral rule of recognition, yet defends the validity of wicked law.

Most importantly, if all law is subject to moral scrutiny and may be justifiably (and sometimes even necessarily) disobeyed, how is it made in any sense 'non-optional or obligatory' unless valid legal obligations are necessarily also moral? In his concept of law, Hart maintains that human beings are not 'free to do what they want,' but that 'are required to do or abstain from certain actions. ${ }^{49}$ However, human beings are only really required to do or abstain from certain actions if they accord with morality. As a result, law without morality does not impose any duty that is either 'non-optional or obligatory.' This reality is already reflected in Hart's assessment; the only rules of obligation he has recognized as absolutely necessary for the existence of law are those relating to the generally accepted moral restrictions on 'the free use of violence, theft, and deception to which human beings are tempted but which they must, in general, repress, if they are to coexist in close proximity to each other. ${ }^{50}$

For this reason, the validity of a law necessarily relates to morality. Unless Hart separates his concept of law from the general idea of obligation, valid law cannot be 'too iniquitous to obey.' The general idea of obligation, as it relates to the notion of a rule, entails that individuals are in some sense restricted by the rule, and that 'deviations from them are not merely grounds for a prediction that hostile reactions will follow or that a court will apply sanctions to those who break them, but are also a reason or justification for such reaction and for applying sanctions. ${ }^{, 51}$ However, Hart's moral question of obedience, as well as his idea for the ex post facto legal sanctioning of wicked legal acts, implies that

\footnotetext{
49 ibid 81, 87.

${ }^{50}$ ibid 91.

51 ibid 84.
} 
individuals are only restricted by, and bound to, morality obligations. This is generally inconsistent with the precepts of the separation thesis.

\section{Conclusion}

In an attempt to defend the conceptual gap between law and morality, Hart develops a theory of law that rejects the possibility of their necessary connection. He admittedly does so for moral reasons, aiming to counter the pervasive effects of wicked law. As a result, his theory of law as a system of rules purposefully seeks to refute the ideas of habit and coercion in order to provide for the internal aspect of law, while also insisting on the positivist separation between what law is and what law ought to be. Despite a thorough justification for this distinction, Hart's attempt is not convincing. His reasoning is logically inconsistent, and often confuses the existence of a separation with the desire for one. As Fuller aptly remarks, it is unclear 'whether in Professor Hart's own thinking the distinction between law and morality simply 'is,' or is something that 'ought to be'., 52

As I have shown, it is clear that the distinction between law and morality has not been proven as one that simply 'is.' If the use of a particular law as an accepted standard of conduct is subject to moral questions of obedience, internal statements of acceptance and validity necessarily reflect the morality of the internal viewpoint. Provided that Hart yields to his theory of law as a system of rules, the assumed moral character of the internal viewpoint indicates that an accepted rule of recognition must generally reflect society's view of what the law ought to be. In addition, the general idea of obligation cannot logically exist under a theory of valid law that is 'too iniquitous to obey,' therefore a correct understanding of amoral legal obligations must either reject the internal viewpoint in favour of the external view of obligation through habits and commands, or reject the capacity for moral reason. However, neither of these reflects the reality of how individuals assess the law or their actions in relation to it.

Neither should the distinction between law and morality be understood as one that 'ought to be.' It is not a desirability given the issues of uncertainty, as well as the overall problems of inconsistency and

\footnotetext{
${ }^{52}$ Fuller (n 6) 631.
} 
absurdity of a valid law 'too iniquitous to obey.' Of course, these problems are remedied through an amoral understanding of acceptance and obedience, however this would be even less desirable and, again, does not reflect the reality of how individuals assess the law or their actions in relation to it.

For these reasons, a moral concept of law is both more logical and more desirable than either Austin or Hart's concepts of law. Hart mistakenly assumes that a necessary connection between valid law and morality would equate morality with law. As a result, he argues that the separation thesis is the most effective way to ensure that law-what the law is - is assessed in relation to morality - what the law ought to be. Not only would a moral understanding of legal validity also maintain a distinction between moral and legal rules, it would also more effectively provide for a moral assessment of the law. By bridging the gap between law and morality, the latter is given hierarchical supremacy. This would likely make men readier to disobey wicked law be eliminating the pressures associated with legal rules, namely the more severe sanctions and the aura of authority caused by the official institutionalization of law. $^{53}$

${ }^{53}$ Hart, Concept of Law (n 1) 86, 169-170. 